\title{
Occurrence of Diverse Recombinant Strains of Potato virus $Y$ Circulating in Potato Fields in Egypt
}

Esraa A. Elwan, Engy E. Abdel Aleem, and Faiza A. Fattouh, Department of Botany and Microbiology, Faculty of Science, Alexandria University, Egypt; Kelsie J. Green and Lisa T. Tran, Department of Plant, Soil, and Entomological Sciences, University of Idaho, Moscow, ID 83844-2339; and Alexander V. Karasev, Department of Plant, Soil, and Entomological Sciences, and Bioinformatics and Computational Biology Program, University of Idaho, Moscow, ID 83844-2339

\begin{abstract}
Potato is one of the staple crops in Egypt, grown under irrigation almost continuously year-round. Potato virus $Y$ (PVY) has been reported as one of the main viruses affecting potatoes in Egypt, but limited information is available on PVY strains circulating in potato fields in the country. From 2014 to 2016, virus surveys were conducted in several potato-growing governorates of Egypt, and PVY-positive samples were found to represent at least five distinct recombinant PVY strains, including PVYNTN and $\mathrm{PVY}^{\mathrm{N}-\mathrm{Wi}}$. Whole genome sequences were determined for four

isolates representing strains PVY-SYR-III (Egypt7), PVY-261-4 (Egypt11), PVY ${ }^{\mathrm{NTNa}}$ (Egypt35), and a novel recombinant named Egypt24 that combined molecular properties of strains PVY-261-4 and PVYWilga156var. At least three recombinants found in Egypt in potato were previously found associated with potato tuber necrotic ringspot disease (PTNRD). The identification of multiple recombinant types of PVY in potato in Egypt, including the novel recombinant Egypt24, suggests a wide presence of PTNRD-inducing virus strains in the country.
\end{abstract}

Viruses affect potato production in two ways: either by affecting tuber yield (Nolte et al. 2004), or by affecting tuber quality. The tuber damage can be internal, like net necrosis caused by Potato leafroll virus (PLRV) (Jayasinghe and Salazar 1998; Peters and Jones 1981) and extensive internal necrosis caused by Alfalfa mosaic virus (AlMV) (Nie et al. 2015; Slack 1981), or external damage like potato tuber necrotic ringspot disease (PTNRD) caused by Potato virus $Y$ (PVY) in susceptible potato cultivars (Beczner et al. 1984; Le Romancer et al. 1994). Tuber quality problems affect the marketable value of the crop and may lead to significant losses in addition to reduction in yields. Hence, the three viruses known to affect tuber quality, PVY, AlMV, and PLRV, are a major concern for potato producers all over the world.

In Egypt, potato is an important staple crop produced under irrigation almost year-round, and virus infections represent a significant burden on potato production (Elawady and Abdulkheir 2015; International Potato Center 2007; Shalaby et al. 2002). Epidemiology of potato viruses in the Middle East is complicated, since the exchange of seed potato between neighboring states in the area is largely absent. A substantial proportion of potato production is targeting European markets, where most seed potato is coming from. The rest is destined for internal consumption in most of the countries of the eastern Mediterranean and the Middle East. Egypt is an exception in the region, since it also exports a significant share of its potato crop to other Arab countries and to Russia (Elawady and Abdulkheir 2015; International Potato Center 2007). Three viruses that can affect potato tuber quality were found in Egypt (Abdalla et al. 2016a, b; El-Absawy et al. 2012; El-Borollosy 2015; El-Helaly et al. 2012).

PVY has long been recognized as a threat to potato cultivation in Egypt (Abdalla et al. 2016b; El-Absawy et al. 2012; El-Borollosy 2015; Shalaby et al. 2002), but only limited studies were conducted to reveal the genomic diversity of PVY population in the country. An isolate of possibly a PVYNTN strain from the Al Daqahlia

Corresponding author: Alexander V. Karasev; E-mail: akarasev@uidaho.edu.

*The $\boldsymbol{e}$-Xtra logo stands for "electronic extra" and indicates that one supplementary table is published online.

Accepted for publication 10 April 2017.

C 2017 The American Phytopathological Society governorate was reported based merely on capsid protein $(\mathrm{CP})$ cistron sequence comparisons (El-Absawy et al. 2012), and another isolate representing the $\mathrm{PVY}^{\mathrm{O}}$ strain was reported from the Al Giza governorate (El-Borollosy 2015). A recent report suggested presence of the PVY ${ }^{\mathrm{NTN}}$ isolates in potato in Asiut, Upper Egypt, based again only on sequence analysis of a small fragment of the genome in the CP region (Abdalla et al. 2016b).

PVY exists as a complex of strains that are classified genetically based on reactions in indicator plants and differential potato cultivars (Cockerham 1970; Jones 1990; Karasev and Gray 2013; Kehoe and Jones 2016; Kerlan 2006; Singh et al. 2008), and also molecularly based on genome sequences and recombinant structures (Karasev and Gray 2013; Singh et al. 2008). At least nine strains have been defined so far, plus a growing number of recombinant variants (Glais et al. 2002; Karasev and Gray 2013; Kerlan 2006; Singh et al. 2008). In recent years, PVY became a major problem for potato production worldwide (Blanchard et al. 2008; Gray et al. 2010; Karasev and Gray 2013) due to the spread of new recombinant strains often associated with induction of PTNRD in susceptible cultivars (Gray et al. 2010). Due to the wide spread of recombinant strains of PVY, partial sequences from the CP region of the virus genome were found insufficient to correctly determine the strain assignment of a virus isolate (Karasev and Gray 2013; Singh et al. 2008). Consequently, either whole genome sequencing or special typing techniques utilizing multiple primers probing for the presence or absence of main recombinant junctions would be necessary to type the PVY recombinants (Chikh-Ali et al. 2013; Lorenzen et al. 2006). Multiple recombinants of PVY have been found in potato in the eastern Mediterranean and the Middle East outside of Egypt, including PVY ${ }^{\mathrm{NTN}}$ and PVY $\mathrm{Y}^{\mathrm{N}-\mathrm{Wi}}$ in Jordan (Anfoka et al. 2014, 2016), PVY-SYR-I, -SYR-II, and -SYR-III in Syria, Jordan, and Saudi Arabia (Anfoka et al. 2014, 2016; Chikh-Ali et al. 2010b, 2016a), and PVY-NE11 in Saudi Arabia (Chikh-Ali et al. 2016a).

To fill in the knowledge gap about the viruses potentially affecting tuber quality in the Nile Delta area of Egypt, we conducted surveys for the three potato viruses in 10 governorates of Egypt during three seasons, 2014 to 2016. Special emphasis was placed on PVY, to identify virus strains present in potato crops grown in the Nile Delta of Egypt. The main objective of this study was to determine the virus genetic diversity present in potato fields, including nearly whole genome sequencing for four recombinant Egyptian isolates of PVY. A novel PVY recombinant type was found in Egypt, not reported previously from any potato-producing area in the world. 


\section{Materials and Methods}

Sample collection. A total of 260 potato leaf samples were collected over the period from 2014 to 2016 from 10 different governorates of the Nile Delta in Egypt as shown in Figure 1. During the survey, leaf samples were collected from plants showing various types of virus-related symptoms such as chlorosis, yellowing, mosaic, necrosis, leaf rolling, or stunted growth. Symptoms were evaluated in the fall season in each of the three years, during the month of November. Most of the potato fields surveyed were small plots of approximately 0.42 hectares $(0.42$ ha $=1.038$ acres $=1$ Feddan, a local unit of area) or less for each, growing commercial potato for local consumption. Potato cultivar names were provided by the plot owners. In all cases they were planted with potato seed produced locally, and not with imported seed. Samples were collected from plants exhibiting virus-like symptoms, and one sample constituted a single symptomatic leaf. All samples were placed in plastic bags kept in a cooler, labeled, and once delivered to the laboratory, kept frozen at $-20^{\circ} \mathrm{C}$ until tested.

Identification of PVY, AIMV, and PLRV infection in collected samples. PVY infection was initially detected using double-antibody sandwich (DAS)-ELISA using the BIOREBA (Reinach, Switzerland) kit for PVY detection, according to the manufacturer's instructions. Subsequently, presence of PVY, PLRV, and AlMV was detected using RT-PCR assays with specific primers after total RNAs were extracted from potato leaf samples using RNeasy Plant Mini kit (QIAGEN, Germantown, MD) according to the manufacturer's instructions. Synthesis of first-strand cDNA and amplification of full-length cDNA were accomplished by using the Tetro cDNA Synthesis Kit (BIOLINE, Taunton, MA) according to manufacturer's instructions. RT-PCR was used for the identification of PVY, PLRV (Shalaby et al. 2002), and AlMV (Blouin et al. 2010) infections. In order to further investigate the 12 randomly select samples collected in 2014 and 2015, RNAs were extracted from these 12 samples and transported as wet ethanol precipitates to the Plant Virology Laboratory at the University of Idaho (UI).

RNA extraction, RT-PCR, and sequencing of PVY positive samples. RNA was isolated from all 12 symptomatic samples using
GeneJET Plant RNA Purification Mini Kit (Thermo Scientific, Waltham, MA) according to manufacturer's instructions. The first-strand cDNA synthesis for the amplification of full-length cDNA products was accomplished according to the method of Chikh-Ali et al. (2013). For strain identification, two different multiplex RT-PCR assays were performed following the methods of Lorenzen et al. (2006) and Chikh Ali et al. (2010a) as described previously (Chikh-Ali et al. 2016a,b; Funke et al. 2017). Control isolates representing nine strains of PVY and additional recombinant variants were obtained from the UI laboratory collection (Chikh-Ali et al. 2013, 2016c). The PCR step was carried out using GreenTaq DNA Polymerase (GenScript, Piscataway, NJ) as previously described (Chikh-Ali et al. 2013). All 12 samples were also screened for the presence of eight other viruses commonly found in potato: PMTV, TRV, AlMV, Potato virus $M$ (PVM), Potato virus A (PVA), Potato virus $X$ (PVX), Potato virus $S$ (PVS), and Potato leafroll virus (PLRV) using RT-PCR. This additional screening was conducted using RTPCR with nine pairs of specific primers (Nie and Singh 2001; Robinson 1992; and newly designed primers) listed in Suppl. Table S1. Laboratory controls for PMTV, TRV, PVM, PVA, PVX, PVS, and PLRV were used in each experiment as total nucleic acids extracted according to Chikh-Ali et al. (2016c).

PVY isolates Egypt7, Egypt11, Egypt24, and Egypt35 (Table 1) were selected for whole genome sequencing, while Egypt3 and Egypt14 were sequenced partially. A series of overlapping PCR fragments amplified on cDNA synthesized from these samples was sequenced directly as described in Green et al. (2017). PCR products were treated with Exosap-It (Affymetrix, Cleveland, OH) and submitted for Sanger sequencing to Genewiz, Inc. (South Plainfield, NJ). Individual sequence reads were assembled using the SeqMan Pro program of the Lasergene 9 Suite (DNASTAR, Madison, WI), with the default parameters. The four nearly whole genome sequences and two partial sequences were deposited in the GenBank database under the accession numbers KY863548 (Egypt11), KY863549 (Egypt7), KY863550 (Egypt24), KY863551 (Egypt 35), KY863552 (Egypt3), and KY863553 (Egypt14).

Sequence analysis. MUSCLE (Edgar 2004) implemented in the program MEGA version 7 (Tamura et al. 2007) was used with the

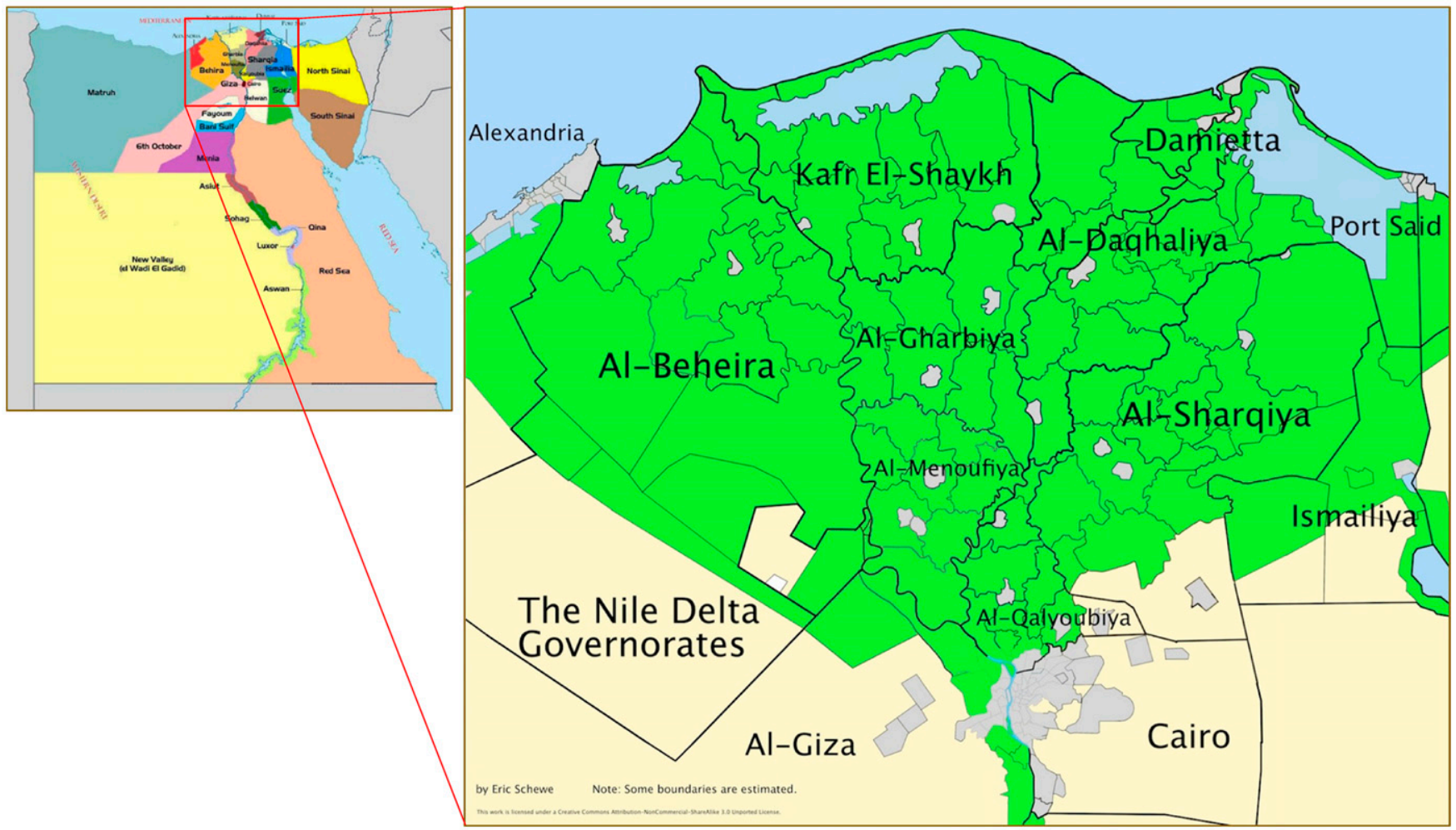

Fig. 1. Map of the Nile Delta governorates of Egypt surveyed for potato viruses during the period from 2014 to 2016 , for a total of 260 collected leaf samples exhibiting virus-like symptoms. Green color designates cultivated areas under irrigation. 
default parameters for the multiple sequence alignment. Alignments were generated based on the whole genomes of representative isolates of all nine characterized PVY strains $\left(\mathrm{PVY}^{\mathrm{O}}, \mathrm{PVY}^{\mathrm{O}}-\mathrm{O} 5, \mathrm{PVY}^{\mathrm{N}}\right.$, $\mathrm{PVY}^{\mathrm{C}}, \mathrm{PNY}^{\mathrm{NA}-\mathrm{N}}, \mathrm{PVY}-\mathrm{NE} 11, \mathrm{PVY}^{\mathrm{N}: \mathrm{O}}, \mathrm{PVY}^{\mathrm{N}-\mathrm{Wi}}$, and PVY $\left.{ }^{\mathrm{NTN}}\right)$, as well as $P V Y^{E}$, the three Syrian types, and the rare PVY-261-4 and PVY-Wilga156var recombinant variants. The aligned sequences were checked for recombination using the RDP, GENECONV, BOOTSCAN, MAXCHI, CHIMAERA, 3Seq, and SiScan methods in the RDP v4.61 software (Martin et al. 2010). The analyses in the RDP 4.61 package were done using default settings and a Bonferroni-corrected $P$-value cut-off of 0.05 . Only recombination points detected as highly statistically significant $(P<0.0001)$ by more than four methods in the RDP 4.61 program were taken into consideration. The phylogeny inference was conducted based on the whole genomes using the neighbor-joining method (NJ) implemented in MEGA version 7 (Tamura et al. 2007) with 1,000 bootstrap replicates. The condensed tree was then generated in MEGA version 7 with a cutoff value of $<70 \%$, so that all nodes with less than $70 \%$ support were collapsed.

\section{Results}

In order to characterize local virus isolates affecting potato in Egypt, a survey was conducted in the main potato production area, in Nile Delta governorates, targeting the three most common viruses, PVY, AlMV, and PLRV. A total of 260 potato leaf samples were collected from local fields in 10 governorates in the Nile Delta area of Egypt (Fig. 1), over a three year period of 2014 through 2016. Collected samples exhibited various virus-like symptoms, such as different types of mosaic (yellow, bright yellow, pale or dark green), leaf necrosis, chlorosis, stunted growth, leaf distortions, or leaf blade rolling. A summary of the initial virus testing is shown in Table 1: 107 samples or $41.2 \%$ were found infected with one or more of the three viruses tested for, i.e., PVY, AlMV, or PLRV. PVY was the most common in the symptomatic samples $(13.5 \%)$, followed by AlMV $(11.5 \%)$ and PLRV (4.6\%). In addition to single infections for each of the three viruses, double and triple infections in different combinations were detected at a relatively low incidence (Table 1). Given the dominance of the PVY infection in symptomatic potato leaf samples, and due to the limited information on PVY strains circulating in potato in Egypt, 12 samples were randomly selected for a more thorough study of genetic diversity and identification of possible recombinants in representative local PVY isolates.

PVY strain typing using RT-PCR assays. Of the 12 randomly selected potato leaf samples subjected to the RT-PCR testing for nine different potato viruses, nine were found positive for PVY (Table 2). Five of the nine PVY-positive samples also contained another potato virus, most often PLRV, while one sample contained both AlMV and PLRV in addition to PVY. Hence, mixed infections were easily found in field potato samples (Table 2). Aside from the three viruses targeted by the survey, namely PVY, AlMV, and PLRV (Table 1), no

Table 1. Summary of the surveys conducted in 10 Nile Delta (Egypt) governorates for Potato virus $Y$ (PVY), Alfalfa mosaic virus (AlMV), and Potato leafroll virus (PLRV). PVY positive samples were detected using DAS-ELISA, and AlMV and PLRV positive samples were detected using RT-PCR, as described in Materials and Methods.

\begin{tabular}{|c|c|c|c|c|c|c|c|c|c|c|c|}
\hline \multirow[b]{2}{*}{ Governorate } & \multirow[b]{2}{*}{ Potato cultivar } & \multirow{2}{*}{$\begin{array}{c}\text { No. of } \\
\text { samples }\end{array}$} & \multicolumn{2}{|c|}{$\begin{array}{c}\text { Total } \\
\text { infected } \\
\text { samples }\end{array}$} & \multirow[b]{2}{*}{ PVY } & \multirow[b]{2}{*}{ PLRV } & \multirow[b]{2}{*}{ AlMV } & \multirow[b]{2}{*}{ PVY+AIMV } & \multirow[b]{2}{*}{ PLRV+AIMV } & \multirow[b]{2}{*}{ PVY+AIMV } & \multirow[b]{2}{*}{ PVY + AMV + PLRV } \\
\hline & & & No. & $\%$ & & & & & & & \\
\hline Alexandria & Barum & 34 & 9 & 26.5 & 4 & 1 & 4 & - & - & - & - \\
\hline Kafr El-Shaykh & Cara & 11 & 5 & 45.5 & 5 & - & - & - & - & - & - \\
\hline Damietta & Spunta/Cara & 38 & 20 & 52.6 & 6 & 1 & 5 & 1 & 1 & 2 & 4 \\
\hline Al-Gharbiya & Spunta/Diamant & 41 & 14 & 34.1 & 3 & 4 & 5 & 2 & - & - & - \\
\hline Al-Sharqiya & Spunta/Diamant & 36 & 19 & 52.7 & 5 & 1 & 3 & 1 & 7 & 2 & 2 \\
\hline Al- Beheira & Spunta/Barum & 34 & 14 & 41.2 & 6 & 1 & 4 & 3 & - & - & - \\
\hline Al-Qualioubiya & Spunta/Barum & 25 & 11 & 44 & 1 & 1 & 6 & 3 & - & - & - \\
\hline Al-Giza & Cara & 3 & 2 & 66.7 & 1 & - & - & - & - & 1 & - \\
\hline Al-Dakahlia & Spunta & 35 & 12 & 34.3 & 4 & 2 & 3 & - & 1 & - & 2 \\
\hline Al-Menoufia & Spunta & 3 & 1 & 33.3 & - & 1 & - & - & - & - & - \\
\hline TOTAL & & 260 & 107 & 41.2 & 35 & 12 & 30 & 10 & 9 & 5 & 8 \\
\hline
\end{tabular}

Table 2. Detailed molecular characterization of a select set of 12 potato samples collected from Nile Delta governorates in Egypt. Potato virus $Y$ (PVY) strain typing was conducted using RT-PCR, with two different primer sets according to Lorenzen et al. (2006) and Chikh Ali et al. (2010a). Potato mop-top virus (PMTV), Tobacco rattle virus (TRV), Alfalfa mosaic virus (AlMV), Potato virus M (PVM), Potato virus A (PVA), Potato virus X (PVX), Potato virus $S$ (PVS), and Potato leafroll virus (PLRV) using RT-PCR.

\begin{tabular}{|c|c|c|c|c|c|c|c|c|c|c|c|c|c|c|c|}
\hline \multirow[b]{2}{*}{ Sample ID } & \multirow[b]{2}{*}{ Governorate } & \multirow{2}{*}{$\begin{array}{l}\text { Potato } \\
\text { cultivar }\end{array}$} & \multicolumn{2}{|c|}{ RT-PCR assay ${ }^{a}$} & \multicolumn{3}{|c|}{ Strain typing call } & \multicolumn{8}{|c|}{ Potato viruses } \\
\hline & & & Lorenzen $^{b}$ & Chikh-Ali ${ }^{\mathrm{c}}$ & RT-PCR & Sequence $^{\mathrm{d}}$ & accession & PMTV & TRV & AIMV & PVS & PVX & PVA & PVM & PLRV \\
\hline Egypt2 & Al Giza & Spunta & - & - & - & - & - & - & - & POS & - & - & - & - & POS \\
\hline Egypt3 & Damietta & Spunta & 181 & 441 & A recombinant & $\mathrm{NTNb}$ ? & KY863552 & - & - & - & - & - & - & - & - \\
\hline Egypt6 & Al Beheira & Spunta & 181,452 & 441,633 & NTNa or PVY-E & - & - & - & - & POS & - & - & - & - & - \\
\hline Egypt7 & Damietta & Spunta & 181,452 & $278,441,1,076$ & SYR-III & SYR-III & KY863549 & - & - & - & - & - & - & - & - \\
\hline Egypt8 & Al Beheira & Spunta & 181,452 & 441,633 & NTNa or PVY-E & - & - & - & - & - & - & - & - & - & - \\
\hline Egypt11 & Al Sharqia & Spunta & 181,689 & 278 & $261-4$ & $261-4$ & KY863548 & - & - & - & - & - & - & - & POS \\
\hline Egypt13 & Al Sharqia & Spunta & 181 & - & A recombinant & - & - & - & - & - & - & - & - & - & POS \\
\hline Egypt14 & Alexandria & Barum & 181 & 441,853 & N-Wi & $\mathrm{N}-\mathrm{Wi}$ & KY863553 & - & - & - & - & - & - & - & - \\
\hline Egypt23 & Al Daqahlia & Spunta & - & - & - & - & - & - & - & - & - & - & - & - & - \\
\hline Egypt24 & Al Daqahlia & Spunta & 181 & 278 & 261-4 (?) & New & KY863550 & - & - & - & - & - & - & - & POS \\
\hline Egypt35 & Al Gharbiya & Spunta & 181,452 & 441,633 & NTNa or PVY-E & $\mathrm{NTNa}$ & KY863551 & - & - & POS & - & - & - & - & POS \\
\hline Egypt108 & Al Shraqia & Spunta & - & - & - & - & - & - & - & - & - & - & - & - & POS \\
\hline
\end{tabular}

\footnotetext{
a Numbers represent PCR product sizes in base pairs (bp).

${ }^{b}$ RT-PCR typing using methodology of Lorenzen et al. (2006).

${ }^{c}$ RT-PCR typing according to Chikh Ali et al. (2010b).

$\mathrm{d}$ Typing based on whole or partial genome sequence analysis.
} 
other major potato viruses were found in these selected samples (Table 2).

All nine PVY-positive samples were identified as representing recombinant strains of PVY, with three typed as $\mathrm{PVY}^{\mathrm{NTNa}}$ or $\mathrm{PVY}^{\mathrm{E}}$, one as PVY-SYR-III, one as PVY ${ }^{\mathrm{N}-\mathrm{Wi}}$, two as PVY-261-4, and two as undefined recombinants (Table 2). No nonrecombinant PVY sequences were found, and no evidence was found for mixed infections between different PVY strains. In most cases, both typing primer sets, Lorenzen et al. (2006) and Chikh-Ali et al. (2010b), identified the presence of the recombinant junction RJ2 at position nt 2,415, characteristic of the main recombinants of PVY (Karasev and Gray 2013).

Sequencing and sequence analysis. Four PVY isolates were subjected to whole genome sequencing: those tentatively assigned by RT-PCR to strains PVY-SYR-III (Egypt7), PVY-261-4 (Egypt11), possibly PVY-261-4 (Egypt24), and PVYNTNa or PVYE (Egypt35). These four sequences represented nearly whole genomes of the respective PVY isolates, missing only 30-70 nt at the extreme 5'end due to the amplification strategy used (Green et al. 2017). Two isolates, Egypt3 and Egypt14, were subjected to partial sequencing that covered about $15 \%$ and $34 \%$ of their genomes, including the 3 '-terminal area. This partial sequencing, together with RT-PCR typing, suggested Egypt3 to be either a PVY ${ }^{\text {NTNa }}$ or PVY ${ }^{\text {NTNb }}$ isolate, and confirmed the RT-PCR assignment of Egypt14 as a PVY ${ }^{\mathrm{N}-\mathrm{Wi}}$ isolate (Table 2). Nearly complete genome sequences of Egypt7, Egypt11, and Egypt35 were subjected to the recombinant analysis using the programs from the RDP package, and found to represent strains PVY-SYR-III (Egypt7), PVY-261-4 (Egypt11), and PVYNTNa (Egypt35), matching the assignments based on the RTPCR typing (Fig. 2; Table 2). The nearly complete sequence of the Egypt24 isolate was found unique: it partly resembled the PVY261-4 strain by having an $\mathrm{N}$-sequence fragment between positions 680 and 2,390, and partly resembled another recombinant named PVY-Wilga156var by having another $\mathrm{N}$-sequence fragment between positions 5,850 and 6,855 (see Fig. 2).

In phylogenetic reconstructions, whole genomes of the four Egyptian isolates were placed in respective clades with PVYNTNa

A

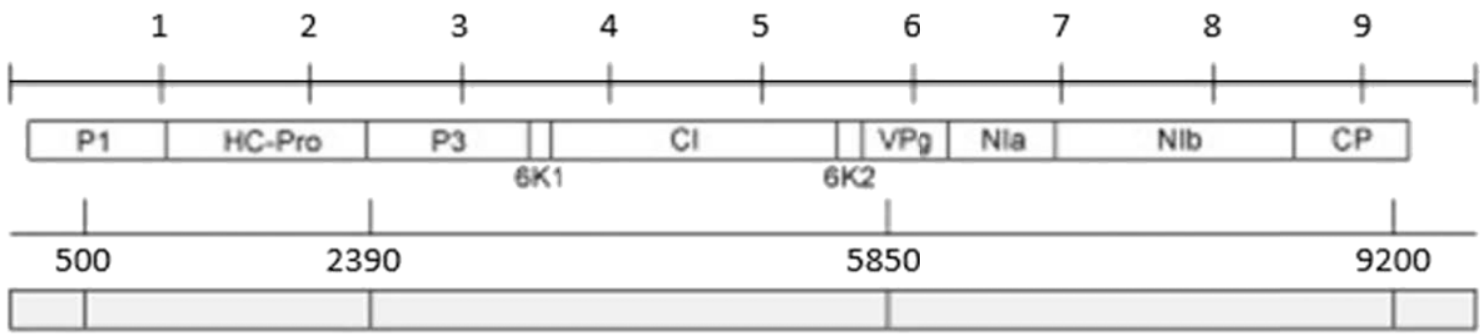

Eu-N

B

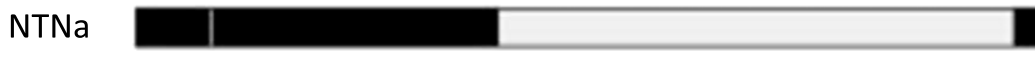

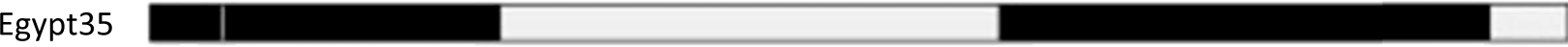

C

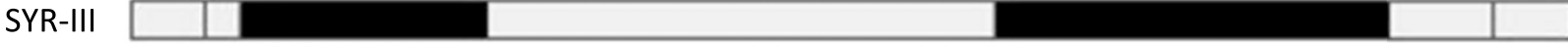

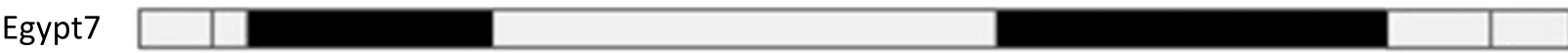

D

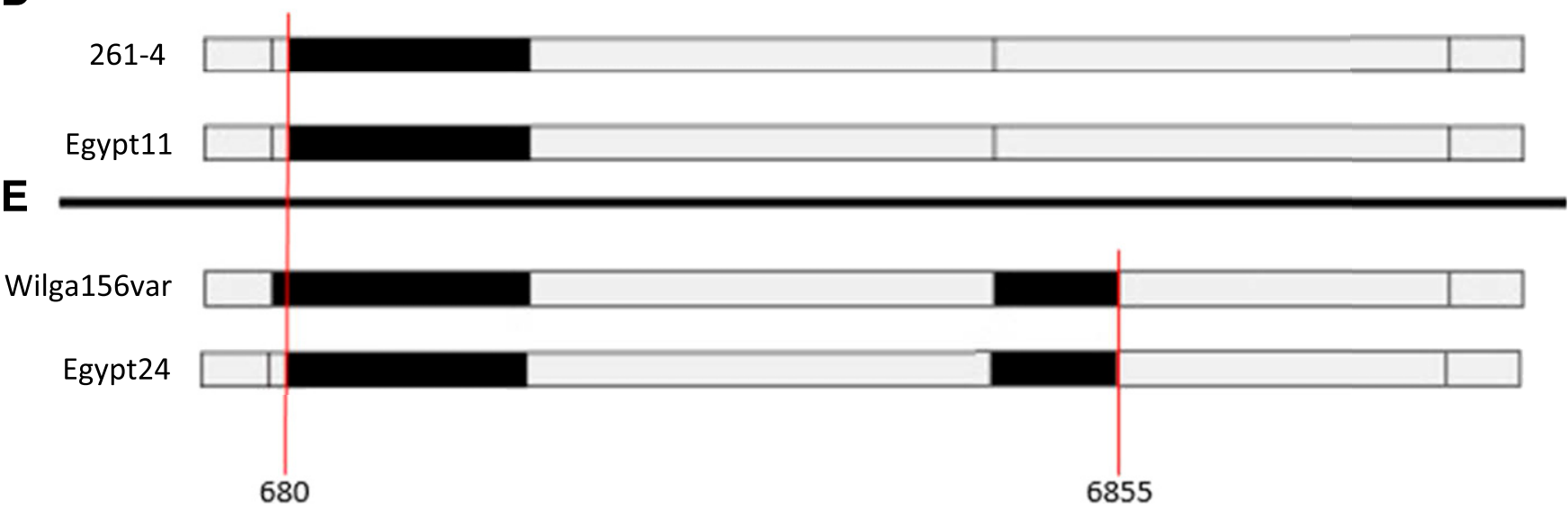

Fig. 2. Summary diagrams of the Potato virus $Y$ (PVY) recombinants identified by sequence analysis in Egyptian potato. (A) A schematic diagram presents the main features of the PVY genome, with individual cistrons marked as unshaded rectangles. Below, two parental genomes, $\mathrm{O}(\mathrm{PVY})$ ) and Eu-N (PVY $)$, are presented as unshaded and shaded in black, respectively. Underneath the parental sequences, four recombinant structures found in PVY isolates collected in Egypt are presented: (B) PVY ${ }^{N T N a}$ (Egypt35); (C) PVY-SYRIII (Egypt7); (D) PVY-261-4 (Egypt11); (E) a new recombinant, distinct from the closest PVY-Wilga156var (Egypt24); positions of the two recombinant junctions are indicated as nt numbers in the alignment. 
(Egypt35), PVY-SYR-III (Egypt7), PVY-261-4 (Egypt11), and PVY-Wilga156var (Egypt24) (Fig. 3). Isolate Egypt7 grouped in the same clade with two isolates from Syria and Saudi Arabia (Fig. 3) belonging to strain PVY-SYR-III (Chikh-Ali et al. 2010a). Interestingly, three other isolates-Egypt11, Egypt24, and Egypt35-each grouped closely with respective isolates from strains PVY-261-4 (accession number AM113988), PVY-Wilga156var (AJ889868), and PVY ${ }^{\mathrm{NTNa}}$ (AJ890345), all reported from Europe (Schubert et al. 2007).

\section{Discussion}

Potato has become a staple crop in Egypt, with over 172,000 ha planted in 2014 (FAOSTAT 2014). In 2014, more than 4.6 million tons of potato were produced in Egypt, with 516,000 tons estimated to be seed potato (FAOSTAT 2014). As a vegetatively propagated crop, potato is prone to virus infections, and viruses affecting tuber quality are of particular concern for potato producers. Here, we conducted a survey in the Nile Delta, one of the major potato producing areas of Egypt, and collected data on the prevalence of three potato viruses affecting tuber quality, PVY, PLRV, and AlMV, during three seasons of observation, 2014 to 2016 (Table 1). Because not all strains of PVY affect tuber quality, we conducted a more detailed study of the strain composition on a subset of the samples collected in 2015.

The diversity of the PVY strains circulating in potato in Egypt was found remarkable - at least five different recombinant types were identified among PVY-positive samples subjected to a detailed study (Table 2; Figs. 2 and 3). No nonrecombinant isolates were found among the tested samples, which was consistent with the similar dominance of recombinant strains of PVY in neighboring Saudi

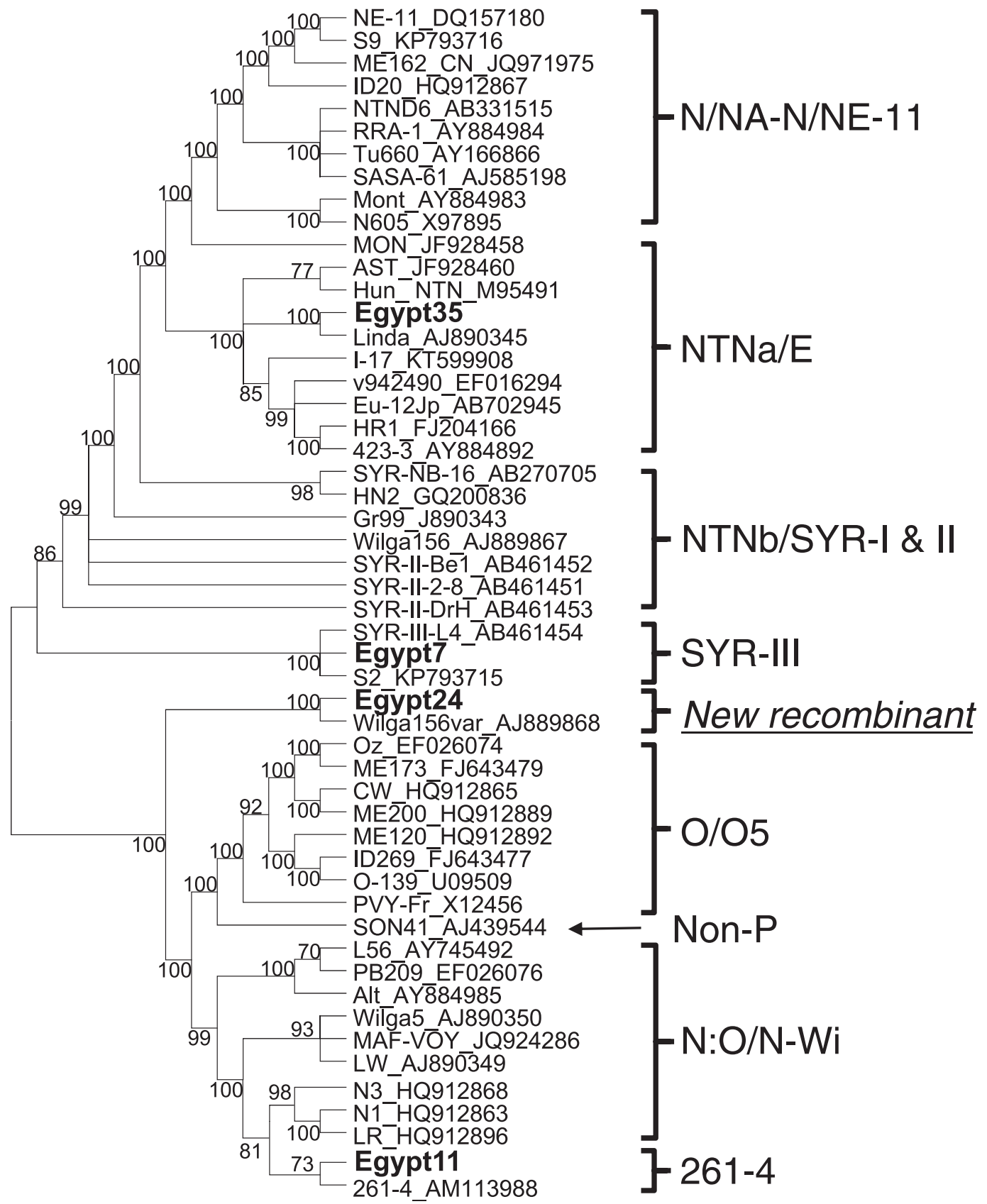

Fig. 3. Phylogenetic analysis of nucleotide sequences of the whole genomes for the four Egyptian and 48 additional, representative PVY isolates conducted with the neighbor joining (NJ) algorithm. Only nodes with bootstrap values $70 \%$ or higher were retained. Brackets designate individual strains and variants of PVY as described in Karasev and Gray (2013); the clade with the new recombinant Egypt24 is designated with an underlined font. 'Non-P' designates a sequence from a non-potato isolate SON41 (PVYC). Bold font designates Egypt7, Egypt11, Egypt24, and Egypt35 sequences. Both an isolate name and a corresponding accession number in the GenBank database are given for each reference sequence. 
Arabia (Chikh-Ali et al. 2016a), Jordan (Anfoka et al. 2014, 2016), and Syria (Chikh Ali et al. 2010b). The suggested presence of a possible $\mathrm{PVY}^{\mathrm{NTNb}}$ isolate based on RT-PCR and partial sequencing that did not span the 5'-proximal segment of the genome should be viewed with caution, as similar indications for Indonesian PVY isolates were not confirmed after whole genome sequencing (Chikh-Ali et al. 2016b). Three of the PVY strains found in Egypt, PVY ${ }^{\mathrm{NTNa}}, \mathrm{PVY}^{\mathrm{N}-\mathrm{Wi}}$, and PVY-SYR-III, were found in Syria and Jordan (Anfoka et al. 2014, 2016; Chikh Ali et al. 2010b), while strain PVY-SYR-III was also found in Saudi Arabia (Chikh-Ali et al. 2016a). On the other hand, the PVY-261-4 strain found in Egypt (Table 2; Fig. 2) was previously reported only once from Germany (Schubert et al. 2007). The newly described strain Egypt24 (Fig. 2) resembled the previously reported strain PVY-Wilga156var from Germany (Schubert et al. 2007). However, the position of the first recombinant junction RJ1 for Egypt24 was located at nt 680 of the whole genome alignment (Fig. 2). It was shifted by approximately $180 \mathrm{nt}$ to the 3 -terminus relative to the RJ1 of Wilga156var, and matched the RJ1 of another European strain described by Schubert et al. (2007), PVY-261-4.

Recent study of the prevalence of PVY strains circulating in the U.S. revealed that recombinant strains dominated in the U.S., and two of them, PVY ${ }^{\mathrm{NTNa}}$ and $\mathrm{PVY}^{\mathrm{N}-\mathrm{Wi}}$, made up almost $80 \%$ of the PVY isolates circulating in potato (Funke et al. 2017), with the rest represented by $\mathrm{PVY}^{\mathrm{O}}, \mathrm{PVY}^{\mathrm{N}: \mathrm{O}}$, and PVY-NE11 strains (Funke et al. 2017). Dominance of recombinant strains of PVY was also demonstrated in Europe (Glais et al. 2002; Schubert et al. 2007; Sihelska et al. 2016), in South America (Galvino-Costa et al. 2012a, b), and in Asia (Anfoka et al. 2014, 2016; Chikh-Ali et al. 2010a, 2016a, b; Schubert et al. 2015). PVY strains PVY-SYR-III, PVY-261-4, and Egypt24 were never found in the U.S. or Canada (Funke et al. 2017; Karasev and Gray 2013; Nie et al. 2013). The remarkable resemblance of PVY recombinants found in potato crops in several countries in the eastern Mediterranean and the Middle East may suggest a common source of the infection, most likely seed potato acquired through international trade. The closest relatives for three of the four Egyptian PVY genomes sequenced were found among the European PVY sequences (Fig. 3), which may suggest that the original source of these recombinants resided somewhere in Europe.

Four of the five recombinant types identified in Egypt, $\mathrm{PVY}^{\mathrm{N}-\mathrm{Wi}}$, PVY-SYR-III, PVY-261-4, and Egypt24, are expected to have an O serotype based on the CP gene sequence (Chikh Ali et al. 2010b; Green et al. 2017; Nikolaeva et al. 2012; Schubert et al. 2007). At the same time, at least three of the identified recombinant strains, PVYNTNa, PVY-SYR-III, and PVY-261-4, were reported to induce PTNRD in susceptible potato cultivars (Chikh Ali et al. 2010b; Le Romancer et al. 1994; Schubert et al. 2007). This unusual combination of the O serotype and PTNRD-inducing capabilities for the PVY strains circulating in Egypt poses special challenges for the diagnosis of the most damaging PVY strains in the country.

\section{Acknowledgments}

This work was supported by the Science and Technology Development Fund (STDF) Project 5564, in Egypt for the survey, identification of viruses, and for travel of Egyptian collaborators to the U.S. It was also funded in part through grants from the Northwestern Potato Research Consortium, the Idaho State Department of Agriculture, the USDA National Institute of Food and Agriculture (NIFA) Hatch project IDA01560, and by the Idaho Agricultural Experiment Station.

\section{Literature Cited}

Abdalla, O. A., Eraky, A. I., Mohamed, S. A., and Fahmy, F. G. 2016a. Molecular identification of viruses responsible for severe symptoms on potato (Solanum sp.) growing in Assiut Governorate (Upper Egypt). Int. J. Virol. Stud. Res. 4: 29-33.

Abdalla, O. A., Eraky, A. I., Mohamed, S. A., and Fahmy, F. G. 2016 b. Phylogenetic analysis of Potato virus $Y$ (PVY) isolate from Upper Egypt proves the widespread of PVY-NTN strain causing PTNRD disease in Egypt. Ann. Virol. Res. 2:1020.

Anfoka, G., Altaleb, M., and Abu-Obaida, M. 2016. First report of Potato virus $Y$ strain N-Wilga affecting potato in Jordan. Plant Dis. 100:2176.

Anfoka, G., Haj-Ahmad, F., Altaleb, M., Abadi, M., Abubaker, S., Levy, D., Rosner, A., and Czosnek, H. 2014. First report of recombinant Potato virus $Y$ strains infecting potato in Jordan. Plant Dis. 98:1017.
Beczner, L., Horvath, H., Romhanyi, L., and Forster, H. 1984. Etiology of tuber ringspot disease in potato. Potato Res. 27:339-352.

Blanchard, A., Rolland, M., Lacroix, C., Kerlan, C., and Jacquot, E. 2008. Potato virus Y: a century of evolution. Curr. Top. Virol. 7:21-32.

Blouin, A. G., Greenwood, D. R., Chavan, R. R., Pearson, M. N., Clover, G. R. G., MacDiarmid, R. M., and Cohen, D. 2010. A generic method to identify plant viruses by high-resolution tandem mass spectrometry of their coat proteins. J. Virol. Methods 163:49-56.

Chikh-Ali, M., Alruwaili, H., Vander Pol, D., and Karasev, A. V. 2016a. Molecular characterization of recombinant strains of Potato virus $Y$ from Saudi Arabia. Plant Dis. 100:292-297.

Chikh-Ali, M., Bosque-Perez, N., Vander Pol, D., Sembel, D., and Karasev, A. V. 2016b. Occurrence and molecular characterization of recombinant Potato virus $Y^{\text {NTN }}\left(\mathrm{PVY}^{\mathrm{NTN}}\right)$ isolates from Sulawesi, Indonesia. Plant Dis. 100:269-275

Chikh-Ali, M., Gray, S. M., and Karasev, A. V. 2013. An improved multiplex ICRT-PCR assay distinguishes nine strains of Potato virus $Y$. Plant Dis. 97: 1370-1374

Chikh Ali, M., Maoka, T., Natsuaki, K. T., and Natsuaki, T. 2010a. The simultaneous differentiation of Potato virus $Y$ strains including the newly described strain PVY ${ }^{\mathrm{NTN}-\mathrm{NW}}$ by multiplex PCR assay. J. Virol. Methods 165:15-20.

Chikh Ali, M., Maoka, T., Natsuaki, T., and Natsuaki, K. T. 2010b. PVY ${ }^{\text {NTN-NW }}$ a novel recombinant strain of Potato virus $Y$ predominating in potato fields in Syria. Plant Pathol. 59:31-41.

Chikh-Ali, M., Vander Pol, D., Nikolaeva, O. V., Melzer, M. J., and Karasev, A. V. 2016c. Biological and molecular characterization of a tomato isolate of Potato virus $Y$ (PVY) of the PVY ${ }^{\mathrm{C}}$ lineage. Arch. Virol. 161: 3561-3566.

Cockerham, G. 1970. Genetic studies on resistance to potato viruses X and Y Heredity 25:309-348.

Edgar, R. C. 2004. MUSCLE: multiple sequence alignment with high accuracy and high throughput. Nucleic Acids Res. 32:1792-1797.

El-Absawy, E. A., Mahmoud, A., Hemeida, A. A., and Helmy, H. 2012. Molecular variation of Potato virus $Y$ isolated from Egypt. Int. J. Virol. 8:81-89.

Elawady, S. I. A., and Abdulkheir, A. Y. 2015. An economic study of the growth determinants of the Egyptian potatoes exports to the global market. Int. J. Econ. Finance 7:89-97.

El-Borollosy, A. M. 2015. Biological, serological and molecular characterization of a potato Y potyvirus strain in Egypt. J. Basic Appl. Sci. Res. 5:65-78.

El-Helaly, H. S., Ahmed, A. A., Awad, M. A., and Soliman, A. M. 2012 Biological and molecular characterization of potato infecting Alfalfa mosaic virus in Egypt. Int. J. Virol. 8:106-113.

FAOSTAT. 2014. Online publication: http://www.fao.org/faostat, accessed Feb 9, 2017.

Funke, C. N., Nikolaeva, O. V., Green, K. J., Tran, L. T., Chikh-Ali, M., Quintero-Ferrer, A., Cating, R., Frost, K. E., Hamm, P. B., Olsen, N., Pavek, M. J., Gray, S. M., Crosslin, J. M., and Karasev, A. V. 2017. Strain-specific resistance to Potato virus $Y$ (PVY) in potato and its effect on the relative abundance of PVY strains in commercial potato fields. Plant Dis. 101:20-28.

Galvino-Costa, S. B. F., dos Reis Figueira, A., Camargos, V. V., Geraldino, P. S., Hu, X.-J., Nikolaeva, O. V., Kerlan, C., and Karasev, A. V. 2012a. A novel type of Potato virus $Y$ recombinant genome, determined for the genetic strain PVY ${ }^{\mathrm{E}}$. Plant Pathol. 61:388-398.

Galvino-Costa, S. B. F., Figueira, A. R., Rabelo-Filho, F. A. C., Moraes, F. H. R. Nikolaeva, O. V., and Karasev, A. V. 2012b. Molecular typing of Potato virus $Y$ isolates from Brazil reveals a diverse set of recombinant strains. Plant Dis. 96: $1451-1458$

Glais, L., Tribodet, M., and Kerlan, C. 2002. Genomic variability in Potato potyvirus $\mathrm{Y}(\mathrm{PVY})$ : evidence that $\mathrm{PVY}^{\mathrm{N}} \mathrm{W}$ and $\mathrm{PVY}^{\mathrm{NTN}}$ variants are single or multiple recombinants between $\mathrm{PVY}^{\mathrm{O}}$ and $\mathrm{PVY}^{\mathrm{N}}$ isolates. Arch. Virol. 147:363-378

Gray, S., De Boer, S., Lorenzen, J., Karasev, A., Whitworth, J., Nolte, P., Singh, R., Boucher, A., and Xu, H. 2010. Potato virus Y: an evolving concern for potato crops in the United States and Canada. Plant Dis. 94: 1384-1397.

Green, K. J., Brown, C. J., Gray, S. M., and Karasev, A. V. 2017. Phylogenetic study of recombinant strains of Potato virus Y. Virology 507:40-52.

International Potato Center. 2007. World Potato Atlas - Egypt. Accessible online: https://research.cip.cgiar.org/confluence/display/wpa/Egypt.

Jayasinghe, U., and Salazar, L. F. 1998. Present status of controlling potato leafroll virus. Pages 584-592 in: Plant Virus Disease Control. A. Hadidi, R. K. Khetarpal, and H. Koganezawa, eds. APS Press, St. Paul, MN

Jones, R. A. C. 1990. Strain group specific and virus specific hypersensitive reactions to infection with potyviruses in potato cultivars. Ann. Appl. Biol. 117:93-105.

Karasev, A. V., and Gray, S. M. 2013. Continuous and emerging challenges of Potato virus $Y$ in potato. Annu. Rev. Phytopathol. 51:571-586.

Kehoe, M. A., and Jones, R. A. C. 2016. Improving Potato virus $Y$ strain nomenclature: lessons from comparing isolates obtained over a 73-year period. Plant Pathol. 65:322-333. 
Kerlan, C. 2006. Potato virus Y. Descriptions of Plant Viruses, no 414. Association of Applied Biologists, UK. Online www.dpvweb.net/dpv/showdpv.php? dpvno=414.

Le Romancer, M., Kerlan, C., and Nedellec, M. 1994. Biological characterization of various geographical isolates of Potato virus $Y$ including superficial necrosis on potato tubers. Plant Pathol. 43:138-144.

Lorenzen, J. H., Piche, L. M., Gudmestad, N. C., Meacham, T., and Shiel, P. 2006. A multiplex PCR assay to characterize Potato virus $Y$ isolates and identify strain mixtures. Plant Dis. 90:935-940.

Martin, D. P., Lemey, P., Lott, M., Moulton, V., Posada, D., and Lefeuvre, P. 2010. RDP3: a flexible and fast computer program for analyzing recombination. Bioinformatics 26:2462-2463.

Nie, X., De Koyner, D., Liang, Z., Dickison, V., Singh, M., and Hawkins, G. 2015. Identification and first report of a potato tuber necrosis-inducing isolate of Alfalfa mosaic virus in Canada. Plant Dis. 99:1658.

Nie, X., Singh, M., Pelletier, Y., and McLaren, D. 2013. Recent advances on Potato virus $Y$ research in Canada. Am. J. Potato Res. 90:14-20.

Nie, X., and Singh, R. P. 2001. A novel usage of random primers for multiplex RTPCR detection of virus and viroid in aphids, leaves, and tubers. J. Virol. Methods 91:37-49.

Nikolaeva, O. V., Roop, D., Galvino-Costa, S. F. B., Figueira, A. R., Gray, S. M., and Karasev, A. V. 2012. Epitope mapping for monoclonal antibodies recognizing tuber necrotic strains of Potato virus Y. Am. J. Potato Res. 89:121-128.

Nolte, P., Whitworth, J. L., Thornton, M. K., and McIntosh, C. S. 2004. Effect of seedborne Potato virus $Y$ on performance of Russet Burbank, Russet Norkotah and Shepody potato. Plant Dis. 88:248-252.
Peters, D., and Jones, R. A. C. 1981. Potato leafroll virus. Pages 68-70 in: Compendium of Potato Diseases. W. J. Hooker, ed. American Phytopathological Society, St. Paul, MN

Robinson, D. J. 1992. Detection of tobacco rattle virus by reverse transcription and polymerase chain reaction. J. Virol. Methods 40:57-66.

Schubert, J., Fomitcheva, V., and Sztangret-Wisniewska, J. 2007. Differentiation of Potato virus $Y$ using improved sets of diagnostic PCR-primers. J. Virol. Methods 140:66-74.

Schubert, J., Thieme, T., Thieme, R., Ha, C. V., and Hoang, G. T. 2015. Molecular and biological characterization of Potato virus $Y$ isolates from Vietnam. J. Phytopathol. 163:620-631.

Shalaby, A. A., Nakhla, M. K., Soliman, A. M., Mazyad, H. M., Hadidi, A., and Maxwell, D. P. 2002. Development of a highly sensitive multiplex reverse transcription- polymerase chain reaction (m-RT-PCR) method for detection of three potato viruses in a single reaction and nested PCR. Arab J. Biotechnol. 5:275-286.

Sihelska, N., Predajna, L., Nagyova, A., Soltys, K., Budis, J., Gubis, J., Mrkvova, M., Kraic, J., Mihalik, D., and Glasa, M. 2016. Detection and molecular characterization of Slovak tomato isolates belonging to two recombinant strains of potato virus Y. Acta Virol. 60:347-353.

Singh, R. P., Valkonen, J. P., Gray, S. M., Boonham, N., Jones, R. A., Kerlan, C., and Schubert, J. 2008. Discussion paper: The naming of Potato virus $Y$ strains infecting potato. Arch. Virol. 153:1-13.

Slack, S. 1981. Alfalfa mosaic virus. Pages 82-84 in: Compendium of Potato Diseases. W. J. Hooker, ed. American Phytopathological Society, St. Paul, MN

Tamura, K., Dudley, J., Nei, M., and Kumar, S. 2007. MEGA: Molecular Evolutionary Genetics Analysis Software Version 4. Mol. Biol. Evol. 24:1596-1599. 